\title{
LEKSIKON MAKIAN DALAM PERTUTURAN BAHASA INDONESIA: KAJIAN SOSIOPRAGMATIK
}

\author{
INDONESIAN SWEAR WORDS: SOCIOPRAGMATIC ANALYSIS
}

\author{
Ridha Mashudi Wibowo ${ }^{{ }^{*}}$ \\ ${ }^{1}$ Fakultas Ilmu Budaya Universitas Gadjah Mada \\ *Corresponding Author: ridha@ugm.ac.id \\ Informasi Artikel:
}

Dikirim: 4/3/2020; Direvisi: 14/6/2020; Diterima: 8/7/2020

\begin{abstract}
This research reveals the use of swear words in Indonesian language speech, including cursing, the referent of swear words, the type of target substance, the factors that influence the use of swearing, and gender: the data analysis used comparative, matching, and introspection methods with a socio pragmatic lens. Speaking pattern is used to know about the factors behind using the swear words. The study results are that the form of the swearing lexicon consists of words, phrases, and clauses. The shorter the form of swearing, the more expressive the name of curses is. The swear words referred to the body, nature, activity, animal, profession, artist/character, food, spirits, kinship, ethnicity, and hometown. The target substance to which abuse is aimed at ignorance, abnormality, something cursed, unlucky, and disgusting. The swear lexicon is spoken more often by men than women.
\end{abstract}

Keywords: conflict, culture, expression, gender, politeness

\begin{abstract}
Abstrak
Penelitian ini bertujuan untuk mengungkap penggunaan leksikon makian dalam pertuturan berbahasa Indonesia, yang meliputi: bentuk makian, referen diacu, jenis substansi sasaran, faktor-faktor yang berpengaruh dalam pemakaian makian, dan perbedaan gender dalam penggunaan makian. Analisis data dalam penelitian ini menggunakan metode komparasi, padan, dan introspeksi dengan sudut pandang sosiopragmatik. Faktor-faktor yang berpengaruh dalam pemakaian leksikon makian dikaji dengan menggunakan formula SPEAKING. Hasil kajian menunjukkan bahwa bentuk leksikon makian berupa kata, frasa, dan klausa. Semakin pendek bentuk makian, semakin ekspresif pemakaian leksikon makian itu. Referen yang diacu oleh leksikon makian terdiri atas: tubuh, sifat keadaan, aktivitas, binatang, profesi, artis/tokoh, makanan, makhluk halus, relasi kekerabatan, etnis, dan daerah asal. Substansi sasaran yang dituju oleh pemakaian makian, yakni: kebodohan, keabnormalan, sesuatu yang terkutuk, ketidakberuntungan, serta sesuatu yang menjijikkan. Leksikon makian lebih sering dituturkan oleh laki-laki, sedangkan perempuan sangat jarang menggunakannya.
\end{abstract}

Kata kunci: konflik, budaya, ekspresi, gender, kesantunan 


\section{PENDAHULUAN}

Manusia memiliki peran sebagai makhluk pribadi dan makhluk sosial. Sebagai makhluk pribadi manusia memiliki privacy untuk mengatur dirinya sendiri, mengembangkan diri, dan menentukan nasibnya sendiri. Saat keperluannya tidak dapat dipenuhi sendiri manusia menjalankan perannya sebagai makhluk sosial. Dalam upaya memenuhi keperluannya itu manusia harus bekerja sama dengan manusia yang lain dalam sebuah interaksi sosial. Media yang paling efektif digunakan manusia dalam interaksi itu ialah bahasa. Dengan bahasa, mereka dapat memenuhi keperluan, bertukar informasi, membina solidaritas, serta mengembangkan kebudayaan. Agar tidak mengalami kesulitan dalam berkomunikasi, ditetapkan konvensi-konvensi yang harus ditaati oleh pemakai bahasa (Pateda, 1990:5). Kepatuhan atas konvensi-konvensi itu dalam komunikasi dapat menjamin manusia untuk saling memahami, sehingga interaksi yang mereka lakukan menjadi dinamis.

Bahasa tidak hanya berfungsi sebagai alat komunikasi, tetapi juga sebagai alat pemersatu, adaptasi, hubungan sosial, dan kritik sosial. Terkait dengan fungsi bahasa itu, Michel (dalam Chaer dan Agustina, 2003:33 membagi fungsi dasar bahasa menjadi lima, yaitu fungsi ekspresi, informasi, eksplorasi, persuasi, dan entertainment.

Fungsi ekspresi ialah fungsi bahasa yang dipakai untuk mengungkapkan atau menyatakan sesuatu. Fungsi informasi adalah fungsi bahasa untuk menyampaikan pesan atau amanat kepada orang lain. Fungsi eksplorasi adalah fungsi pemakaian bahasa untuk menjelaskan suatu hal, perkara, atau keadaan. Fungsi persuasi ialah fungsi bahasa yang dipergunakan untuk memengaruhi seseorang secara baik-baik untuk melakukan sesuatu atau tidak melakukannya. Fungsi entertainment ialah fungsi bahasa yang dipakai untuk menghibur, menyenangkan, dan memuaskan perasaan batin.

Dalam realitas sosial, interaksi antarmanusia tidak selalu berjalan lancar. Faktor penyebabnya antara lain: penguasaan bahasa, perbedaan pengalaman, latar belakang pendidikan, dan ekspektasi atas berbagai kepentingan. Interaksi yang tidak berjalan lancar atau tidak sesuai dengan harapan dapat menimbulkan masalah pada pihak-pihak yang terlibat, seperti perbedaan pendapat, pertengkaran, dan rasa ketidaknyamanan. Sindiran, makian, atau kata-kata kasar adalah salah satu dampak yang ditimbulkan oleh keterlibatan emosi atas ketidaklancaran interaksi itu.

Bagi pelakunya, makian dapat menjadi outlet atas tekanan psikologis yang ditanggungnya selama interaksi. Kata-kata kasar melepaskan semua himpitan psikologis atas kebuntuan selama berinteraksi. Kata-kata itu umumnya dipakai untuk menghina, meremehkan, mengungkapkan kekecewaan, atau atau keterkejutan.

Sementara itu, bagi orang yang terkena dampaknya kata-kata kasar dapat dianggap sebagai ancaman atau serangan atas kemerdekaan pribadinya, penghinaan atas martabatnya, atau penghapusan eksistensi dirinya dalam interaksi (Wijana, 2004:242). Kata-kata kasar, makian, atau sindiran itu secara sosial merupakan bagian dari wilayah tabu yang dalam pergaulan pada umumnya digantikan dengan ungkapan-ungkapan eufemistis atas alasan kesopanan/kesantunan.

Pemakaian makian biasa dihindari karena potensinya untuk menimbulkan antipati dan amarah orang yang menjadi target atas kata-kata bermakna buruk itu. Karena makian dipakai untuk menyatakan perasaan dan melepaskan diri dari tekanan ketidaklancaran interaksi, katakata itu berfungsi emotif dan ekspresif (Jakobson, 1960; Leech, 1976). 
Pemakaian makian dapat dikaji secara pragmatik. Pragmatik mengkaji makna secara eksternal, yaitu makna yang terikat dengan konteks. Pemahaman konteks sangat diperlukan dalam analisis pragmatik. Leech (1993:20) mengartikan konteks sebagai suatu pengetahuan latar belakang yang sama-sama dimiliki oleh penutur dan petutur dan yang membantu petutur menafsirkan makna tuturan. Tindak tutur (speech act) merupakan komponen utama analisis pragmatik. Yule (1996:239) menyatakan bahwa dalam banyak cara, tuturan adalah bentuk dari identitas sosial dan digunakan secara sadar atau tidak untuk mengindikasikan keanggotaan dalam perbedaan kelompok sosial atau perbedaan masyarakat tutur.

Sementara itu, Wijana (2009) membagi tindak tutur menjadi dua bagian pengelompokan. Pertama ialah pengelompokan berdasarkan modus dan fungsinya. Pengklasifikasian yang dihasilkan ialah tindak tutur langsung dan tindak tutur tidak langsung. Tindak tutur langsung terjadi apabila fungsinya sesuai dengan modusnya sedangkan tindak tutur tidak langsung apabila fungsi tuturan tidak sesuai dengan modus kalimat. Kedua ialah pengelompokan tindak tutur literal dan tidak literal. Tindak tutur literal ialah tindak tutur yang maksudnya sama dengan kata-kata penyusunnya, sedangkan tindak tutur tidak literal ialah tindak tutur yang maksudnya tidak sama dengan kata-kata penyusunnya. Kedua pengelompokan tersebut dapat dikombinasikan sehingga hadir tindak tutur langsung literal, tindak tutur tidak langsung literal, tindak tutur langsung tidak literal, dan tindak tutur tidak langsung tidak literal.

Selanjutnya, dalam kajian pragmatik dikenal prinsip kerja sama dengan tujuan memperlancar proses komunikasi antara pembicara dan lawan bicara. Grice membagi prinsip kerja sama menjadi empat maksim (Wijana, 2009:42). Maksim pertama adalah maksim kuantitas, maksim ini menghendaki peserta pertuturan untuk memberi kontribusi secukupnya. Maksim kualitas ialah maksim yang menghendaki peserta tutur memberikan kontribusi mengenai kebenaran, didasarkan pada bukti-bukti yang memadai. Maksim relevansi mengharuskan peserta percakapan memberi kontribusi yang relevan terhadap masalah pembicaraan. Maksim terakhir ialah maksim pelaksanaan yang mengharuskan peserta percakapan berbicara secara langsung, tidak kabur, tidak taksa, runtut, dan tidak berlebihlebihan. Dengan keempat maksim tersebut prinsip kerja sama dengan tujuan berbahasa sebagai bagian dari tindakan sosial dapat tercapai.

Sementara itu, prinsip lain pada ilmu pragmatik ialah prinsip kesopanan. Prinsip kesopanan ini terdiri atas beberapa maksim, yakni maksim kebijaksanaan, maksim kemurahan, maksim penerimaan, maksim kerendahan hati, maksim kecocokan, dan maksim kesimpatian. Prinsip ini berhubungan dengan dua peserta percakapan, diri sendiri (penutur) dan orang lain (lawan tutur atau orang ketiga). Maksim kebijaksanaan dan maksim kemurahan merupakan maksim yang berpusat pada orang lain dan maksim penerimaan serta maksim kerendahan hati berpusat pada diri sendiri. Keempat maksim tersebut berhubungan dengan keuntungan atau kerugian bagi diri sendiri dan orang lain. Dua maksim lainnya, maksim kecocokan dan maksim kesimpatian berkaitan dengan penilaian baik atau buruk penutur terhadap diri sendiri atau orang lain.

Pembicaran mengenai kata makian tampaknya tidak dapat dilepaskan dari pembicaraan mengenai kata afektif. Menurut Sudaryanto (1989:83-84) kata afektif dapat pula disebut kata emotif atau ekspresif atau bisa juga kata emotif-ekspresif. Istilah yang agak populer ialah kata berkadar atau bernilai rasa. Penyebutan itu bersangkutan dengan makna. 
Dalam pada itu, aktivitas memaki dapat diasumsikan sebagai bentuk komunikasi yang bersifat interpersonal atau interactional, yaitu fungsi untuk menjalin hubungan, memelihara, memperlihatkan perasaan bersahabat, atau solidaritas sosial (Finnocchiaro, 1974; Halliday, 1973 dalam Chaer dan Agustina, 2003). Aktivitas/perilaku itu dapat dibedakan menjadi tiga, yakni (1) perilaku spontan (spontaneus behaviour), yakni perilaku yang dilakukan atas tuntutan emosi tanpa sensor atau revisi secara kognitif yang terjadi begitu saja, (2) perilaku menurut kebiasaan (script behaviour) yaitu perilaku yang dipelajari dari kebiasaan yang bersifat khas, dilakukan pada situasi tertentu, dan dimengerti orang, (3) perilaku sadar (contrived behaviour), yaitu perilaku yang dipilih karena dianggap sesuai dengan situasi yang ada. Perilaku itu dipikirkan dan dirancang sebelumnya, dan dissuaikan dengan orang yang dihadapi, urusan yang harus diselesaikan, dan situasi, serta kondisi yang ada.

Dalam penelusuran pustaka terkait kajian tentang pemakaian makian telah banyak dilakukan oleh beberapa peneliti, antara lain: (1) Wardani (2008), (2) Prasetya (2011), (3) Andrianti (2006), (4) Sunarti (2007), (5) Saptomo (2001), (6) Yunita (2012), (7) Najmi (2014), (8) Damanhuri (2007), dan (9) Wijana (2004). Akan tetapi, penelitian ini memiliki perbedaan dengan penelitian-penetian tersebut.

Dalam penelitian ini, makian dalam bahasa Indonesia dikaji dari beberapa segi, yakni bentuknya, referennya, substansi sasarannya, fungsi pemakaiannya, dan faktor-faktor sosial yang memengaruhinya. Secara terperinci, permasalahan yang dikaji dalam penelitian ini adalah sebagai berikut: (1) bentuk makian apa sajakah yang digunakan dalam pertuturan berbahasa Indonesia, (2) referen apa sajakah yang diacu dalam sistem makian berbahasa Indonesia, (3) apa saja substansi sasaran yang dicapai oleh penggunaan makian dalam bahasa Indonesia, (4) bagaimana faktor-faktor yang berpengaruh bekerja dalam pemakaian makian dalam tuturan, dan (5) bagaimana korelasi gender terhadap aktivitas memaki dalam pertuturan.

\section{METODE}

Data penelitian diambil dari pertuturan, komik, kamus, tulisan dalam media cetak, dan komentar dalam media sosial. Data diperoleh dengan metode simak dan catat, selanjutnya dianalisis menggunakan metode komparasi, padan, dan introspeksi. Analisis data dalam penelitian ini menggunakan sudut pandang sosiopragmatik. Faktor-faktor yang berpengaruh dalam pemakaian leksikon makian dianalisis menggunakan formula SPEAKING dari Hymes (dalam Chaer dan Agustina, 1995:62) atau yang biasa disebut delapan komponen tutur, yaitu Setting and scene, Participants, Ends: Purpose and Goal, Act Sequences, Key: Tone or Spirit of Act, Instrumentalities, Norms of Interaction, dan Genres.

\section{HASIL DAN PEMBAHASAN Bentuk Makian}

Bentuk makian diklasifikasikan berdasarkan hierarki bahasa dan pembentukannya. Berdasarkan hierarki bahasa, bentuk makian terdiri atas kata, frasa, dan klausa. Berdasarkan pembentukannya bentuk kata dapat dibedakan atas kata dasar dan kata turunan. Dalam kata turunan dapat diuraikan lagi menjadi afiksasi, pemajemukan, dan diftongisasi. Berikut disajikan contoh-contohnya dalam cetak miring. 
Tabel 1. Bentuk Leksikon Makian

\begin{tabular}{|c|c|c|c|c|c|c|c|}
\hline \multicolumn{2}{|l|}{ No. } & \multicolumn{2}{|c|}{ Strata Bentuk } & \multicolumn{2}{|c|}{ Contoh } & $\Sigma$ & $\%$ \\
\hline \multirow{6}{*}{1.} & \multirow{6}{*}{ Kata } & \multicolumn{2}{|c|}{ Kata dasar } & $\begin{array}{l}\text { Anjing, minggat kau dari } \\
\text { sini! } \\
\text { Dasar sundal tak tahu } \\
\text { diuntung. }\end{array}$ & $\begin{array}{l}\text { Jahanam, mati kau! } \\
\text { Setan.. kemana dia? }\end{array}$ & 28 & 26,6 \\
\hline & & \multirow{5}{*}{$\begin{array}{l}\text { Kata } \\
\text { Tu- } \\
\text { runan }\end{array}$} & Afiksasi & $\begin{array}{l}\text { Terkutuk kalian! } \\
\text { Mati kau, penjahat! }\end{array}$ & Bajingan, jangan lari! & 11 & 10,5 \\
\hline & & & \multirow{2}{*}{$\begin{array}{l}\text { Kata Maje- } \\
\text { muk }\end{array}$} & $\begin{array}{l}\text { Kurang ajar, kembalikan } \\
\text { sepedaku! }\end{array}$ & Asu buntung, siapa kau? & \multirow[b]{2}{*}{18} & \multirow[b]{2}{*}{17,1} \\
\hline & & & & $\begin{array}{l}\text { Kepala batu.. dibilangin } \\
\text { gak percaya.. }\end{array}$ & Dasar kambing congek.. & & \\
\hline & & & \multirow[b]{2}{*}{$\begin{array}{l}\text { Diftongi- } \\
\text { sasi }\end{array}$} & $\begin{array}{l}\text { Guoblog.. gitu aja gak } \\
\text { bisa.. }\end{array}$ & $\begin{array}{l}\text { Kuampret.. jatahku } \\
\text { ditilep. }\end{array}$ & & \\
\hline & & & & $\begin{array}{l}\text { Pueliiiitt.. awas kamu } \\
\text { ya.. }\end{array}$ & Jiancoookk.. & 6 & 5,7 \\
\hline \multirow[t]{2}{*}{2.} & Frase & & & $\begin{array}{l}\text { Dasar Cina.. parkir yang } \\
\text { bener woooii. }\end{array}$ & Matamu taro di mana? & 18 & 17,1 \\
\hline & & & & $\begin{array}{l}\text { Lunas lunas gimana.. tai } \\
\text { kucing. }\end{array}$ & Mulutmu somplakk.. & & \\
\hline \multirow[t]{2}{*}{3.} & Klausa & & & $\begin{array}{l}\text { Modar kau.. salah sen- } \\
\text { diri! }\end{array}$ & Dasar babi ngepet!! & 14 & 13,3 \\
\hline & & & & $\begin{array}{l}\text { Kaga dikasi jatah bulan- } \\
\text { an.. mampus } l u !\end{array}$ & Sapi ompooong.. & & \\
\hline
\end{tabular}

Dari 95 kuesioner yang kembali diperoleh perhitungan dan persentase seperti tersebut di dalam tabel di atas. Berdasarkan jumlahnya dapat diketahui bahwa bentuk dasar lebih banyak muncul dibandingkan bentuk-bentuk lain disebabkan oleh keleluasaannya saat digunakan dalam tuturan. Sementara itu, leksikon makian bentuk diftongisasi paling sedikit muncul karena di dalamnya digunakan penyangatan/ emphasis dengan permainan vokal. Dapat diduga bentuk semacam itu biasanya dipakai oleh penutur berdialek Jawa Timuran.

\section{Referen Makian}

Berdasarkan data yang telah terkumpul leksikon makian dapat memiliki acuan tubuh, sifat, keadaan, aktivitas, binatang, profesi, artis/tokoh, makanan, makhluk halus, relasi kekerabatan, etnis, dan daerah asal. Berikut disajikan contoh leksikon yang mewakili dalam cetak miring.

Tabel 2. Referen Leksikon Makian

\begin{tabular}{|c|c|c|c|c|}
\hline No. & Referen & Contoh & $\Sigma$ & $\%$ \\
\hline 1. & Tubuh & $\begin{array}{l}\text { Dasar mata keranjang.. liat yang bening dikit ajah udah ngiler. } \\
\text { Hidung belang lu ya.. bini orang diembat juga. }\end{array}$ & 12 & 11,4 \\
\hline 2. & Sifat & $\begin{array}{l}\text { Pelit..kasi dikit ajah napa? } \\
\text { Kepo lu.. mau tau urusan orang aja. }\end{array}$ & 9 & 8,6 \\
\hline 3. & Keadaan & $\begin{array}{l}\text { Edan.. tiga piring disikat habis. } \\
\text { Celaka.. lakinye dateng tuh.. }\end{array}$ & 7 & 6,6 \\
\hline
\end{tabular}




\begin{tabular}{|c|c|c|c|c|}
\hline 4. & Aktivitas & $\begin{array}{l}\text { Sukurin ditangkep polisi tu orang! } \\
\text { Ngocol masa aku dibilang ceking sih? }\end{array}$ & 6 & 5,7 \\
\hline 5. & Binatang & $\begin{array}{l}\text { Woooii kebo budeg.. dah sore gini lom bangun juga? } \\
\text { Dari tadi makan mulu lu.. sapi ompong. } \\
\text { Ee monyet.. kalo brenti jangan mendadak gtu napa? }\end{array}$ & 16 & 15,2 \\
\hline 6. & Profesi & $\begin{array}{l}\text { Asal deket cowok ajah matanya jelalatan.. dasar lonte. } \\
\text { Maliiiiiingg.. balikin helm guaaa.. } \\
\text { Dasar perek dirayu pake motor butut ajah diembat.. }\end{array}$ & 8 & 7,6 \\
\hline 7. & Artis/tokoh & $\begin{array}{l}\text { Ga denger gue ngomong.. dasar Bolot. } \\
\text { Mau jadi Don Juan lu ya? }\end{array}$ & 6 & 5,7 \\
\hline 8. & Makanan & $\begin{array}{l}\text { Eee kerak telor.. ngapain hari gini di mari? } \\
\text { Kalo liat tu ye pake mata dodol! }\end{array}$ & 8 & 7,6 \\
\hline 9. & Makhluk halus & $\begin{array}{l}\text { Anak kecil malem gini masih kelayapan dasar tuyul. } \\
\text { Iblis.. mana mobil gue, hah? }\end{array}$ & 7 & 6,6 \\
\hline 10. & $\begin{array}{l}\text { Relasi } \\
\text { kekerabatan }\end{array}$ & $\begin{array}{l}\text { Emang ini jalan moyang lu? } \\
\text { Gitu ajh dah lupa lagi? Dasar nenek. }\end{array}$ & 6 & 5,7 \\
\hline 11. & Etnis & $\begin{array}{l}\text { Jawa lu ye.. ngomong medok bener sih? } \\
\text { Dasar Cina apa-apa diitung pake uang.. }\end{array}$ & 5 & 4,8 \\
\hline 12. & Daerah asal & $\begin{array}{l}\text { Ee Batak.. kalo ngomong pelan dikit dong. } \\
\text { Papua gila.. maunya berantem mulu. }\end{array}$ & 5 & 4,8 \\
\hline
\end{tabular}

Perhitungan dan persentase dari 95 kuesioner yang kembali dapat disebutkan dalam tabel di atas. Berdasarkan jumlahnya dapat diketahui bahwa referen binatang paling banyak dipakai daripada acuan lain disebabkan sifat binatang yang dianggap bodoh, malas, tak berguna, dan sebagainya. Sementara itu, referen etnis dan daerah asal memiliki jumlah terkecil dimungkinkan karena karakter lokal itu dianggap menjadi ciri tetap dari budaya lawan tutur yang bersangkutan.

\section{Substansi Sasaran}

Berdasarkan substansi sasarannya leksikon makian dapat dikelompokkan sebagai berikut. Berikut disajikan contoh leksikon yang mewakili dalam cetak miring.

Tabel 3. Substansi Sasaran Leksikon Makian

\begin{tabular}{|c|c|c|c|c|}
\hline No. & Substansi Sasaran & Contoh & $\Sigma$ & $\%$ \\
\hline 1. & Kebodohan & $\begin{array}{l}\text { Jadi dua tambah dua tu lima ya.. dasar otak udang. } \\
\text { Otakmu di dengkul ya..? masa ngecek bensin pake korek sih.. }\end{array}$ & 23 & 21,9 \\
\hline 2. & Keabnormalan & $\begin{array}{l}\text { Namanya juga oon.. giliran ketemu cowoknya ajah ga mau } \\
\text { ngomong. } \\
\text { Eee budeg.. susah bener dibilangin ya.. kalo jalan pake mata } \\
\text { dong! }\end{array}$ & 18 & 17,1 \\
\hline 3. & $\begin{array}{l}\text { Sesuatu yang } \\
\text { terkutuk }\end{array}$ & $\begin{array}{l}\text { Apa? Boncengan sama kamu? Najis, tau? Haramlah gue } \\
\text { nyontek.. biar muka kriminal gue belajar semaleman yee.. }\end{array}$ & 11 & 10,5 \\
\hline 4. & Ketidakberuntungan & $\begin{array}{l}\text { Sial.. dia malah ngikut si kribo!! } \\
\text { Celaka tigabelas.. abis duit guee. }\end{array}$ & 8 & 7,6 \\
\hline 5. & $\begin{array}{l}\text { Sesuatu yang } \\
\text { menjijikkan }\end{array}$ & $\begin{array}{l}\text { Jorok banget sih jadi orang.. mainan upil di bawah meja. } \\
\text { Kumuh lo.. baju kotor lo gantung } 2 \text { di belakang pintu. }\end{array}$ & 12 & 11,4 \\
\hline
\end{tabular}


6. Sesuatu yang mengganggu

Ungkapan
pragmatis
Eee.. tukang sayur.. kalo tereak-tereak di jalan sonoh.

Lo jadi Pak Ogah ya? Minta duit mulu..

Kalian memang buaya.. sukanya mainin anak gadis orang. Gentong nasi ga tau diuntung.. sukanya makaaan aja yang dipikirin.

Dalam tabel di atas diperlihatkan bahwa perhitungan dan persentase substansi sasaran cukup terlihat perbedaannya. Substansi kebodohan cukup banyak dipakai orang dengan anggapan bahwa orang lain diasumsikan lebih bodoh, tidak cakap, atau tidak berkemampuan daripada penutur. Sementara itu, jumlah leksikon yang dipakai karena dipakai untuk memaki sesuatu yang mengganggu jumlahnya tidak besar. Hal ini dimungkinkan karena intensitas 'gangguan' kepada penutur tidak besar, sehingga leksikon yang disampaikan pun dominan berupa pelabelan orang lain dengan profesi yang dianggap kurang berprestise.

\section{Faktor-faktor yang Berpengaruh dalam Pemakaian Leksikon Makian}

Dengan menggunakan formula SPEAKING dari Hymes (via Chaer dan Agustina 1995:62) dapat diuraikan sejumlah faktor yang berpengaruh dalam penggunaan leksikon makian sebagai berikut.

\section{Setting and Scene}

Setting atau latar bersifat fisik yang meliputi tempat dan waktu terjadinya tuturan. Sementara scene adalah latar psikis yang mengacu pada suasana psikologis yang menyertai peristiwa tutur (Mulyana, 2005:23). Tempat dan waktu yang berbeda itu dapat menyebabkan situasi yang berbeda. Dalam budaya Indonesia, Jawa pada khususnya, aktivitas memaki merupakan tindakan yang boleh dikatakan tidak etis, melampaui batas norma kesopanan, dan seringkali dianggap tabu.

Mengingat referen leksikon makian pada umumnya dianggap tidak baik banyak anggota masyarakat cenderung memilih ungkapan eufemistis untuk menggantikan leksikon makian itu. Diharapkan dengan penggunaan kata yang bernuansa eufemisme relasi antarpersonal dapat dijaga keutuhannya dan konflik dapat dihindarkan. Oleh karenanya, aktivitas memaki cenderung dilakukan saat keadaan terdesak ketika penutur merasa 'dirugikan', 'terlukai', atau 'tidak dihargai eksistensinya'.

Tuturan memaki cenderung dilakukan dengan amat ekspresif dalam media lisan yang menuntut kehadiran lawan tuturnya. Sementara di media lain boleh dikatakan intensitasnya menurun atau 'kurang mengena' disebabkan berbagai pertimbangan, misalnya faktor budaya, faktor sosial, faktor media, dan faktor dampak pemakaian leksikon makian itu.

\section{Participants}

Partisipants (peserta), adalah pihak-pihak yang terlibat dalam pertuturan, bisa pembicara dan pendengar, penyapa dan pesapa, atau pengirim dan penerima pesan (Chaer \& Agustina, 2010:48). Dalam hal ini, leksikon makian dapat dipergunakan oleh siapa saja sejauh tujuan penggunaannya terpenuhi.

Berdasarkan tingkat usia dapat dikatakan bahwa dapat ditengarai sekarang sejumlah siswa Sekolah Dasar telah mulai menggunakan leksikon makian saat dirinya dirugikan dan ingin membalas perlakuan lawan tuturnya secara seketika, emosional, dan ekspresif. 
Penggunaan leksikon makian pada tingkat-tingkat di atasnya dapat dikatakan telah biasa dilakukan bergantung keperluannya.

Berdasarkan tingkat pendidikan dapat dikatakan bahwa dominan pengguna leksikon makian adalah orang yang pendidikannya tidak teramat tinggi. Orang-orang berpendidikan tinggi lebih memiliki kesadaran atas potensi kerugian dirinya saat menggunakan leksikon makian, sehingga ditempuh sejumlah cara lain yang lebih memungkinkan untuk mengekspresikan emosinya, misalnya dengan memakai sejumlah kata kias, diksi tertentu, redaksi yang lebih represif, dan sebagainya.

Berdasarkan profesinya pengguna leksikon makian cenderung memiliki lapangan pekerjaan yang berkaitan dengan pekerjaan kasar. Tekanan pekerjaannya memiliki potensi konflik lebih besar daripada pengguna yang memiliki pekerjaan yang lebih berhubungan dengan aktivitas berpikir. Selain itu, berdasarkan status sosialnya dapat dikatakan bahwa stratifikasi sosial yang membedakan masyarakat kelas atas dan bawah menunjukkan bahwa pengguna leksikon makian dominan adalah kelompok masyarakat kelas bawah.

Berdasarkan gendernya pengguna leksikon makian dominan adalah laki-laki dibandingkan dengan perempuan. Amat dimungkinkan hal ini disebabkan pribadi laki-laki yang lebih terbuka, terus terang, dan apa adanya sementara wanita lebih tertutup dan tidak mudah berterus terang. Sejauh ini, para ahli psikologi banyak berkesimpulan bahwa bahasa laki-laki dan perempuan memiliki perbedaan pada nada dan intonasi.

Selanjutnya, perempuan kerap jadi subordinasi kaum laki dalam bahasa yang diwujudkan pada berbagai unsur kosa kata, ungkapan, istilah, dan tataran gramatikalnya. Hal ini sudah menggejala hampir ke semua ranah. Misalnya saja dalam bidang pekerjaan asusila, pada perempuan melekat istilah PSK, pelacur, lonte, murahan, tante girang, dan sejenisnya, sementara bagi lelaki yang melakukan 'pekerjaan' yang sama, hanya mendapat istilah "hidung belang" dan "mata keranjang". Hal ini menunjukkan bahwa subordinasi bahasa terhadap perempuan lebih banyak daripada untuk kaum laki.

\section{Ends}

End (akhir) merujuk pada maksud dan tujuan pertuturan. Leksikon makian digunakan orang untuk berbagai tujuan atau keperluan. Berikut disajikan contoh leksikon yang dipakai untuk aneka keperluan itu yang dimunculkan dalam bentuk cetak miring.

Tabel 4. Tujuan Pemakaian Leksikon Makian

\begin{tabular}{|c|c|c|c|c|}
\hline No. & Tujuan Pemakaian & Contoh & $\Sigma$ & $\%$ \\
\hline 1. & Sarana keakraban & $\begin{array}{l}\text { Jancuk.. lama ga ketemu ke mana aja kamu? } \\
\text { Gimana kabarmu, (mo)nyet.. lama ga nongol lu.. }\end{array}$ & 6 & 5,7 \\
\hline 2. & Sarana persuasi & $\begin{array}{l}\text { Anjrit kok dia bisa lulus sih? } \\
\text { Kecebong, kapan aku pernah malakin kamu? }\end{array}$ & 4 & 3,8 \\
\hline 3. & Pengungkap rasa & $\begin{array}{l}\text { Waaahh, gila.. kok bisa gol ya? } \\
\text { Edaaaann.. Smes tajem gtu bisa mis.. }\end{array}$ & 12 & 11,4 \\
\hline 4. & Sarana olok-olok & $\begin{array}{l}\text { Modar.. salah sendiri ngaku-ngaku jomblo. } \\
\text { Bandot tua sekalinya muncul klimis banget mukanya. }\end{array}$ & 8 & 7,6 \\
\hline
\end{tabular}




\begin{tabular}{|c|c|c|c|c|}
\hline 5. & Sapaan & $\begin{array}{l}\text { Bajingan.. kapan kamu dateng? } \\
\text { (An)jay.. tumben lu bawa boil... }\end{array}$ & 6 & 5,7 \\
\hline 6. & Pengabaian & $\begin{array}{l}\text { Dia itu kecil.. ga usah pedulikan } \\
\text { Paling cuma segitu bisanya.. }\end{array}$ & 9 & 8,6 \\
\hline 7. & Penyindiran & $\begin{array}{l}\text { Si botak ga ada kabarnya lagi ya? } \\
\text { Bukunya dibawa si pincang tadi. }\end{array}$ & 7 & 6,7 \\
\hline 8. & Kemarahan & $\begin{array}{l}\text { Bangsatt.. laptopku raib!! } \\
\text { Dasar kebo.. bukannya minggir malah parkir di jalan.. }\end{array}$ & 9 & 8,6 \\
\hline 9. & Keterkejutan & $\begin{array}{l}\text { Anjritt.. sukanya ngagetin orang.. } \\
\text { E monyet.. monyeett.. monyet.. kaget guwe.. }\end{array}$ & 6 & 5,7 \\
\hline 10. & Kekecewaan & $\begin{array}{l}\text { Yaaahh.. tai kucing.. flashdisknya ketinggalan. } \\
\text { Semprul.. tau gtu kuhabiskan cendolmu. }\end{array}$ & 5 & 4,8 \\
\hline 11. & Ketidakpercayaan & $\begin{array}{l}\text { Sumpeh looo.. ?? } \\
\text { Gajah bengkak.. kok bisaaa?? }\end{array}$ & 3 & 2,9 \\
\hline 12. & Kejengkelan & $\begin{array}{l}\text { Kampreeeett.. } \\
\text { Kadal kebon.. awas yaaa!! }\end{array}$ & 6 & 5,7 \\
\hline 13. & Penghinaan & $\begin{array}{l}\text { Anak tolol.. } \\
\text { Kingkong sarap.. }\end{array}$ & 6 & 5,7 \\
\hline 14. & Penyumpahan & $\begin{array}{l}\text { Weeerr.. weeerr.. matamu asu. } \\
\text { Dasar kecoak bunting.. }\end{array}$ & 5 & 4,8 \\
\hline 15. & Pelecehan & $\begin{array}{l}\text { Udah gembrot jalannya menuhin gang pula.. } \\
\text { Si mata juling kabarnya juara } 3 \text { ya? }\end{array}$ & 3 & 2,9 \\
\hline
\end{tabular}

Dalam tabel di atas diperlihatkan perhitungan dan persentase penggunaan leksikon makian dalam berbagai keperluan. Keperluan pengungkap rasa mendapat persentase terbesar karena kata makian dipakai untuk mengekspresikan perasaan tertentu oleh penuturnya, sementara keperluan pengungkap ketidakpercayaan dan pelecehan sama-sama mendapat porsi terkecil dibandingkan dengan keperluan yang lain dimungkinkan karena frekuensi keperluannya tidak tinggi dalam pelecehan.

Klasifikasi tujuan pemakaian di atas dibuat tidak bersifat hitam putih. Artinya, amat dimungkinkan bahwa contoh yang disajikan boleh jadi dipakai untuk keperluan yang lain sejauh ia dapat mengekspresikan perasaan penuturnya terhadap lawan tuturnya.

\section{Act Sequences}

Act sequence (urutan tindak), mengacu pada bentuk ujaran dan isi ujaran. Bentuk ujaran berkenaan dengan kata-kata yang digunakan, bagaimana penggunaannya, dan hubungan antara apa yang dikatakan dengan topik pembicaraan. Bentuk ujaran dalam kuliah umum, dalam percakapan biasa, dan dalam pesta adalah berbeda. Begitu juga dengan isi yang dibicarakan (Chaer dan Agustina, 2010:49).

Leksikon makian pada umumnya mengikuti relasi stimulus dan respon yang terjadi dalam pertuturan antara penutur dan lawan tuturnya. Dalam hal itu, leksikon makian biasanya merupakan respon dari suatu peristiwa yang dipicu oleh lawan tuturnya. Karena stimulus yang dilakukan lawan tuturnya cenderung merupakan face-threatening act (FTA) leksikon makian dipakai orang sebagai tindakan balasan karena dianggap mengancam kehormatan penutur. Oleh karena itu, menjadi aneh jika ada leksikon makian yang dilontarkan tanpa ada stimulus 
FTA apa pun. Sangat dimungkinkan pula lontaran leksikon makian itu ditimpali juga dengan kata makian oleh lawan tuturnya, sehingga aktivitas pertuturan itu dapat berakhir dengan konflik atau keakraban.

Penggunaan leksikon makian dapat dipergunakan secara ekabahasa atau dwibahasa. Secara ekabahasa kata makian muncul dengan menggunakan media bahasa yang sama, misalnya leksikon makian bahasa Indonesia yang digunakan dalam percakapan berbahasa Indonesia. Sementara itu, secara dwibahasa leksikon makian dipergunakan dalam media bahasa yang berbeda, misalnya leksikon makian bahasa Jawa dipakai dalam percakapan berbahasa Indonesia. Di dalam pertuturan dwibahasa itu amat dimungkinkan terjadi peristiwa alih kode atau campur kode.

Proses alih kode dilakukan karena penutur tidak menguasai kedua kode bahasa secara sama baiknya, sementara campur kode dilakukan saat kedua kode bahasa itu dikuasai sama baiknya, sehingga kadang dilakukan secara tak sengaja. Contoh pemakaian leksikon ekabahasa, misalnya "Kaga dikasi jatah bulanan.. mampus lu!" dan "Jorok banget sih jadi orang.. mainan upil di bawah meja." Contoh penggunaan leksikon dwibahasa ialah "Woooii kebo budeg.. dah sore gini lom bangun juga?" dan "Semprul.. tau gtu kuhabiskan cendolmu."

\section{Key}

Key (kunci), mengacu pada nada, cara, dan semangat saat pesan disampaikan: dengan senang hati, dengan serius, dengan singkat, dengan sombong, dengan mengejek, dan sebagainya. Hal ini dapat juga ditunjukan dengan gerak tubuh dan isyarat (Chaer dan Agustina, 2010:49). Selain itu, Sumarsono (2013:330) mengatakan kunci juga melibatkan satuan-satuan lingustik.

Dari data tuturan yang diperoleh seperti terlihat dalam tabel 4 dapat dinyatakan bahwa satuan leksikal makian pada umumnya diproduksi dengan suara lantang, bernada tinggi, ekspresif, kadang disertai dengan mata melotot, atau gesture mengancam. Leksikon makian diproduksi sebagai pengungkap rasa dan sarana untuk menjalin keakraban, persuasi, olokolok, dan penanda berbagai ekspresi, seperti kemarahan, keterkejutan, kekecewaan, ketidakpercayaan, kejengkelan, da penyumpahan.

\section{Instrumentalities}

Instrumentalities (instrumentalitas) mengacu pada jalur bahasa yang digunakan, seperti jalur lisan, tertulis, melalui telegram atau telepon. Instrumentalities mengacu pada kode ujaran yang digunakan, seperti bahasa, dialek, ragam, atau register (Chaer dan Agustina, 2010:49).

Dari kuesioner yang terkumpul dapat diketahui bahwa data yang diperoleh ialah data tertulis dalam bentuk kata, frase, dan klausa. Dominan datanya diperoleh dalam kode bahasa Indonesia, dan sedikit dalam kode bahasa Jawa. Data dalam bahasa Indonesia dapat diterima dengan pertimbangan bahwa responden yang disadap datanya dominan adalah mahasiswa dan penyadapan data dilakukan di sela-sela perkuliahan. Sementara itu, data dalam bahasa Jawa dimungkinkan diperoleh sebagai bentuk code switching atau code mixing karena bentuk yang sepadan dalam bahasa Indonesia tidak ditemukan. 


\section{Norms}

Norms of interaction and interpretation (norma interaksi dan interpretasi) mengacu pada norma atau aturan dalam berinteraksi, misalnya yang berhubungan dengan cara berinterupsi, bertanya, dan sebagainya. Juga mengacu pada norma penafsiran terhadap ujaran dari lawan bicara (Chaer dan Agustina, 2010:49). Seperti telah disampaikan pada bagian 2.4.4 bahwa pemakaian leksikon makian merupakan respon dari relasi stimulus dan respon yang terjadi dalam pertuturan antara penutur dan lawan tuturnya. Pemakaian leksikon makian merupakan bagian dari face-threatening act (FTA) yang dapat dianggap mengancam kehormatan penutur. Dalam percakapan yang berkelanjutan leksikon makian dapat dipakai sebagai 'serangan' dan atau 'balasan' yang pada akhirnya dapat berujung konflik atau keakraban.

\section{Genre}

Genre (jenis/aliran) dimaksudkan sebagai kategori-kategori seperti puisi, mite, dongeng, peribahasa, teka-teki, cacian (kutukan), doa, orasi, kuliah, perdagangan, surat edaran, editorial, dan sebagainya (Sumarsono, 2013:333). Menurut Richards, dkk. (1985) dalam Sumarsono (2013:233) mengemukakan beberapa kategori genre yang sama dengan sebelumnya, yaitu doa, kotbah, cakapan, nyanyian, pidato, puisi, surat, dan novel. Dengan demikian, dapat diketahui bahwa pemakaian leksikon makian termasuk ke dalam genre cacian dan atau kutukan.

\section{SIMPULAN}

Berdasarkan uraian di atas dapat dinyatakan bahwa penelitian ini mendapatkan sejumlah hasil sebagai berikut. Pertama, Bentuk leksikon makian dapat diuraikan menjadi tiga, yakni kata, frasa, dan klausa. Semakin pendek bentuk makian dapat dikatakan semakin ekspresif pemakaian leksikon makian itu. Kedua, referen yang diacu oleh leksikon makian terdiri atas tubuh, sifat keadaan, aktivitas, binatang, profesi, artis/tokoh, makanan, makhluk halus, relasi kekerabatan, etnis, dan daerah asal. Ketiga, substansi sasaran yang dituju oleh pemakaian leksikon makian ialah kebodohan, keabnormalan, sesuatu yang terkutuk, ketidakberuntungan, sesuatu yang menjijikkan, sesuatu yang mengganggu, dan ungkapan pragmatis lainnya. Keempat, faktor-faktor yang berpengaruh dalam pemakaian leksikon makian dapat diuraikan dengan menggunakan formula SPEAKING Hymes. Kelima, dengan memperhatikan unsur participants dalam formula SPEAKING itu dapat diketahui bahwa gender perempuan relatif tak banyak menggunakan leksikon makian daripada laki-laki dalam korelasinya dengan kecenderungan kepribadiannya yang introvert, tak terbuka, dan enggan berterus terang, berbeda dengan laki-laki yang lebih terbuka, ekspresif, dan terus terang.

\section{DAFTAR PUSTAKA}

Andrianti, R. 2006. "Makian dalam Komik Silat Karya Koo Ping Hoo: Studi tentang Distribusi, Bentuk, Referen, dan Fungsi”. Skripsi. Yogyakarta: Fakultas Ilmu Budaya.

Chaer, A. dan Agustina, L. 1995. Sosiolinguistik: Suatu Pengantar. Jakarta: Rineka Cipta.

Chaer, A. dan Agustina, L. 2003. Psikolinguistik: Kajian Teoretik. Jakarta: Rineka Cipta.

Chaer, A. dan Agustina, L. 2010. Sosiolinguistik: Perkenalan Awal. Jakarta: Rineka Cipta. 
Damanhuri, A. 2007. "Makian dalam Bahasa Madura". Tesis. Yogyakarta: Fakultas Ilmu Budaya.

Jakobson, R. 1960. "Linguistic and Poetic" dalam Style and Language (T.A. Sebeok, ed.). Cambridge, Mass: MIT Press.

Leech, G. 1976. Semantics. Harmondsworth: Middlesex: Penguin Books.

Leech, G. 1993. Prinsip-prinsip Pragmatik. Jakarta: Universitas Indonesia.

Mulyana, D. 2005. Ilmu Komunikasi Suatu Pengantar. Bandung: Remaja Rosdakarya

Najmi, R.A.K.L. 2014. "Swear Words in the Movie Midnight Run". Tesis. Yogyakarta: Fakultas Ilmu Budaya.

Pateda, M. 1990. Sosiolinguistik. Bandung: Angkasa.

Prasetya, I.K.E.A. 2011. “Sistem Makian Bahasa Bali”. Skripsi. Yogyakarta: Fakultas Ilmu Budaya.

Saptomo, S.W. 2001. "Makian dalam Bahasa Jawa". Tesis. Yogyakarta: Fakultas Ilmu Budaya.

Sudaryanto. 1989. Pemanfaatan Potensi Bahasa: Kumpulan Karangan Sekitar dan Tentang Satuan Lingual Bahasa Jawa yang Berdaya Sentuh Inderawi. Yogyakarta: Kanisius.

Sumarsono. 2013. Sosiolinguistik. Yogyakarta: Pustaka Pelajar.

Sunarti, S. 2007. "Makian dalam Bahasa Melayu Bengkulu". Skripsi. Yogyakarta: Fakultas Ilmu Budaya.

Wardani, M.M.S. 2008. "Penggunaan Makian di Kalangan Pelajar: Studi Kasus di SMA Kolese De Britto Yogyakarta”. Skripsi. Yogyakarta: Fakultas Ilmu Budaya.

Wijana, I D.P. 2004. "Makian dalam Bahasa Indonesia: Studi tentang Bentuk dan Referensinya". Humaniora, 16 (3):242-251.

Wijana, I D.P. 2009. Analisis Wacana Pragmatik: Kajian Teori dan Analisis. Surakarta: Yama Pustaka.

Yule, G. 1996. The Study of Language. $2^{\text {nd }}$ Ed. Cambridge: Cambridge University Press.

Yunita, K. 2012. "Penggunaan Ungkapan Makian pada Era Orde Lama, Orde Baru dan PascaOrde Baru: Kajian Sosiolinguistik dalam Film Indonesia Tahun 1949-2010". Skripsi. Yogyakarta: Fakultas Ilmu Budaya. 